\title{
Insertion of intrauterine device for doctors and nurses in a low-risk maternity hospital
}

\author{
Inserção de dispositivo intrauterino por médicos e enfermeiros \\ em uma maternidade de risco habitual \\ Inserción del dispositivo intrauterino para doctores y \\ enfermeras en una maternidad de riesgo habitual
}

\section{Tatiane Herreira Trigueiro ${ }^{a}$ \\ Gisele Szalow de Lima ${ }^{a}$ \\ Rayssa Borges ${ }^{\mathrm{a}}$ \\ Paulo Ricardo Bittencourt Guimarães ${ }^{b}$ \\ Silvana Regina Rossi Kissula Souza ${ }^{a}$ Marilene Loewen Walla}

How to cite this article:

Trigueiro TH, Lima GS, Borges R, Guimarães PRB, Souza SRRK, Wall ML. Insertion of intrauterine device for doctors and nurses in a low-risk maternity hospital. Rev Gaúcha Enferm. 2021;42:e20200015. doi: https://doi.org/10.1590/19831447.2021.20200015
'Universidade Federal do Paraná (UFPR), Departamento de Enfermagem. Curitiba, Paraná, Brasil.

${ }^{\circ}$ Universidade Federal do Paraná (UFPR), Departamento de Estatística. Curitiba, Paraná, Brasil.

\section{ABSTRACT}

Objective: To characterize the production related to the insertion of Intrauterine Devices by doctors and nurses in a low-risk maternity hospital.

Method: Cross-sectional exploratory research, with retrospective collection of secondary data from medical records of women who received the device in a low-risk maternity hospital in Curitiba, Paraná, over 12 months. Data collected between October/2017 to March/2018 that underwent descriptive analysis and Chi-square test.

Results: 0 the 828 insertions, there was a significant difference between women who received the IUD at the Obstetric Center (247) and Ambulatory (571) in terms of the expulsion rate $(p=0.00001)$, with a greater chance of expulsion in the immediate postpartum period (0dds ratio 8.73), there was no significant difference between nurses (481) and doctors (347) $(p=0.07)$, however, more chance of expulsion when the doctor was (0dds ratio 3.60). The main complications were dysmenorrhea and vaginosis.

Conclusion: The insertion of the IUD in the ambulatory by the nurse proved to be as safe as by the doctor.

Keywords: Intrauterine devices. Women's health. Family planning (public health). Nursing.

\section{RESUMO}

Objetivo: Caracterizar a produção referente a inserção de Dispositivos Intrauterinos por médicos e enfermeiros em uma maternidade de risco habitual.

Método: Pesquisa exploratória transversal, com coleta retrospectiva de dados secundários de prontuários de mulheres que receberam o dispositivo em maternidade de risco habitual em Curitiba, Paraná, ao longo de 12 meses. Dados coletados entre outubro/2017 a março/2018 que passaram por análise descritiva e Teste Qui quadrado.

Resultados: Das 828 inserções, existiu diferença significativa entre mulheres que receberam o DIU no Centro Obstétrico (247) e Ambulatório (571) quanto a taxa de expulsão $(p=0,00001)$, existindo mais chance de expulsão no pós-parto imediato (Odds ratio 8,73), não existiu diferença significativa entre enfermeiros (481) e médicos (347) $(p=0,07)$, contudo, mais chance de expulsão quando foi o médico (Odds ratio 3,60). As principais intercorrências foram dismenorréia e vaginose.

Conclusão: A inserção do DIU no ambulatório pelo enfermeiro se demonstrou tão segura quanto pelo médico.

Palavras-chave: Dispositivos intrauterinos. Saúde da mulher. Planejamento familiar. Enfermagem.

\section{RESUMEN}

Objetivo: Caracterizar la producción referente a la inserción de dispositivos intrauterinos por parte de médicos y enfermeras en un hospital de maternidad de riesgo habitual.

Método: investigación exploratoria transversal, con recopilación retrospectiva de datos secundarios de registros médicos de mujeres que recibieron el dispositivo en un hospital de maternidad de riesgo habitual en Curitiba, Paraná, durante 12 meses. Datos recopilados entre octubre/2017 a marzo/2018 que se sometieron a un análisis descriptivo y prueba de Chi-cuadrado.

Resultados: De las 828 inserciones, hubo una diferencia significativa entre las mujeres que recibieron el DIU en el Centro de Obstetricia (247) y Ambulatorio (571) en términos de la tasa de expulsión ( $p=0.00001$ ), con una mayor probabilidad de expulsión en el período posparto inmediato (Odds ratio 8.73), no hubo diferencias significativas entre enfermeras (481) y médicos (347) ( $p=$ 0.07), sin embargo, hubo más posibilidades de expulsión cuando era médico (0dds ratio 3.60). Las principales complicaciones fueron dismenorrea y vaginosis.

Conclusión: la inserción del DIU en el ambulatorio por parte de la enfermera resultó ser tan segura como la realizada por el médico. Palabras clave: Dispositivos intrauterinos. Salud de la mujer. Planificación familiar. Enfermería. 


\section{口INTRODUCTION}

Currently, Brazilian public health services provide eight contraceptive methods free of charge, namely diaphragm, condom, pill and combined hormonal injection, pill and injection only of progesterone and the copper Intrauterine Device (IUD) ${ }^{(1)}$.

The IUD consists of a solid object of variable shape, inserted by the cervix, to be allocated in the uterine cavity, with the main purpose of avoiding pregnancy. There are different presentations of this device, such as copper and hormonal ones, however the Brazilian Ministry of Health makes copper IUD available for free, with Tcu380A being the most used ${ }^{(1-2)}$.

The IUD is effective for up to 12 years after its placement and causes an inflammatory reaction due to a foreign body in the uterine cavity. This reaction, caused by biochemical and morphological changes, produces minimal endometrial tissue damage capable of rendering the environment sterile, altering cervical mucus and having spermicidal action, preventing pregnancy. Thus, it is worth mentioning that ovulation is not affected ${ }^{(2)}$.

As for its effectiveness, the World Health Organization (WHO) claims to be $99.4 \%$, that is, from the correct use, the chances of pregnancy are around $0.6 \%$. Since, among women who choose copper IUD, about $78 \%$ remain with it for at least one year ${ }^{(3)}$. And according to the Manual of Medical Criteria for eligibility for contraceptive use ${ }^{(4)}$, scientific evidence indicates conditions for which there is no restriction on the use of copper IUD, as indicated for both nulliparous and multiparous women, after delivery, preferably immediately after the delivery of the placenta or after four weeks; after cesarean section; after abortion in the first trimester and for women who have contraindications for the use of hormones such as smokers, obese, with a history of breast cancer in family.

Although safe, there are some risks after insertion such as uterine perforation, infection, expulsion, contraceptive failure and ectopic pregnancy. And, it is worth mentioning that, this method does not protect against sexually transmitted diseases, and must be associated with a barrier method ${ }^{(2)}$. A systematic review published by Cochrane showed that there is a greater risk of expulsion of the IUD when inserted in the immediate postpartum, however, the authors reinforce that the benefit of providing effective contraception right after delivery can overcome this disadvantage, and that clinical monitoring and education in health can help to detect signs and symptoms of complications $s^{(5)}$. Thus, counseling in reproductive planning needs to go beyond the delivery of contraceptive methods, but focus on sexual and reproductive health education and expanding options.

The attention and the incorporation of reproductive planning in the nurse's daily and care practice occurs through the support of the Law of professional practice $7.498 / 86^{(6)}$ and through the Nursing Consultation, as part of the systematization of Nursing care supported by the resolution $358 / 2009^{(7)}$ whether in primary care, as well as in maternity hospitals. Thus, if the IUD is the woman's choice and she is in clinical compliance with her current health condition, in addition to the medical professional, the technical opinion $17 / 2010^{(8)}$ of the Federal Nursing Council, emphasizes that, as long as they receive due training, there is no impediment for nurses to perform IUD insertion to users of the Unified Health System, although such practice is still subject to constant analysis and discussion of its legality.

Thus, the role of nurse with a view to reproductive planning occurs, in addition to the provision and guidance of contraceptive methods, also through knowledge and implementation of existing health policies in the country and municipality, engagement in health education, search for technical and scientific knowledge as to the best scientific evidence.

From the search for national literature on the practice of IUD insertion by nurses, there was a shortage of published articles, thus, the development of this research has become relevant as it is necessary to know the population assisted by these professionals and disseminate actions that can assist in supporting the insertion of the IUD by nurses in Brazil. In view of the above, the following questions emerged: What is the production of doctors and nurses regarding the insertion of an IUD in a maternity hospital? What are the indicators regarding the IUD expulsion rate? Thus, the objective was to characterize the production referring to the insertion of Intrauterine Devices by doctors and nurses in a low-risk maternity hospital.

\section{METHOD}

This is a cross-sectional exploratory quantitative research with retrospective collection of secondary data. Medical records of women who had an IUD inserted in a low-risk maternity in the city of Curitiba, Paraná, from August 2016 to August 2017 were collected. This period comprises the first year of IUD insertion by the nurse professional, since before this procedure was performed only by doctors. All medical records of women who received the IUD during this period were included, totaling 828.

The insertions of IUD in this maternity occur in two places, in the Obstetric Center, immediate postpartum, are performed only by doctors and in the Outpatient Clinic where doctors and nurses perform the insertion for women seen in the late postpartum period and those who opted for the IUD as a contraceptive method without necessarily having deliveries at the maternity hospital. The maternity hospital recommends that women who have an IUD inserted go 
through a consultation with the doctor or nurse 30 to 40 days after placing the Device in the Outpatient Clinic.

The data were collected between October 2017 and March 2018 and the medical records were gathered from a control form filled out by an administrative sector employee. Subsequently, information was read and collected in the medical record and an instrument containing the following data was fed: date and place of IUD insertion, age, schooling, gestational history, reason for choosing the method, professional responsible for inserting the IUD, clinical indications, hysterometry, complications during insertion, evaluation of the 30 day return and other eventual returns that occurred in the period.

The data were organized in an Excel spreadsheet and analyzed by means of descriptive analysis and the Chi-square test, complemented by the calculation of Odds ratio (OR), through the program Statistics version 7.0, with a significance level of $5 \%$.
The research complies with the Ethics Criteria in Research with Human Beings in accordance with Resolution 466/12 of the National Health Council and was approved by the institutional Ethics Committee on September 25, 2017, under Statement No.2,294,265.

\section{RESULTS}

From the analysis of the 828 medical records, regarding the location of the IUD insertion, it was found that 581 (70.17\%) occurred in the Outpatient Clinic and 247 (29.83\%) in the Obstetric Center procedures. The average age of women was 25.97 years, with a minimum age of 14 and a maximum of 44 years, with a standard deviation of 6.27. Being the most prevalent age group between 20 and 25 years. Regarding schooling, it is noteworthy that 352 (42.51\%) had completed high school and the sum of women with complete and incomplete higher education reached 187 (22.59\%) according to Table 1.

Table 1 - Age and schooling of women with IUD implantation in a low-risk maternity hospital - Curitiba, PR, Brazil, 2016-2017 (n=828)

\section{Variables}

\section{Age}

\begin{tabular}{|c|c|c|}
\hline up to 15 years & 13 & 1.57 \\
\hline 15 to 20 years & 148 & 17.87 \\
\hline 20 to 25 years & 273 & 32.97 \\
\hline 25 to 30 years & 209 & 25.24 \\
\hline 30 to 35 years & 111 & 13.41 \\
\hline 35 to 40 years & 56 & 6.76 \\
\hline 40 to 45 years & 17 & 2.05 \\
\hline 45 to 50 years & 1 & 0.12 \\
\hline \multicolumn{3}{|l|}{ Schooling } \\
\hline None & 1 & 0.12 \\
\hline Incomplete Elementary School & 102 & 12.32 \\
\hline Complete Elementary School & 60 & 7.25 \\
\hline Incomplete High School & 106 & 12.80 \\
\hline Complete High School & 352 & 42.51 \\
\hline Complete Higher Education & 98 & 11.84 \\
\hline Incomplete Higher Education & 89 & 10.75 \\
\hline No information & 20 & 2.42 \\
\hline
\end{tabular}

Source: Research data, 2016-2017. 
Regarding parity, 260 (31.40\%) of the women were first pregnancy and 241 (29.11\%) were second pregnancy and as for the time of insertion of the IUD, 231 (27.89\%) occurred in the immediate postpartum period, 15 after curettage $(1.81 \%)$ and one $(0.12 \%)$ received the IUD with sedation, 335 (40.45\%) in the late postpartum period and $246(29.71 \%)$ by direct search at the Outpatient Clinic.

As an indication for using the copper IUD as a contraceptive method, 556 (67.15\%) lactating women, 10 (1.21\%) smokers, five (0.60\%) hypertensive, two (0.24\%) with a history breast cancer and one (0.12\%) diagnosed with epilepsy.

As for the professional responsible for inserting the IUD in the maternity ward, 481 (58.09\%) was performed by nurses and 347 (41.91\%) by doctors. At the Outpatient Clinic, 581 insertions were performed, of which 481 (82.79\%) were performed by nurses and 100 (17.21\%) by doctors.

Regarding hysterometry, 548 records were found, the average was 8.06 centimeters $(\mathrm{cm})$, with a minimum of 6 $\mathrm{cm}$, a maximum of $12 \mathrm{~cm}$, with a standard deviation of 0.84 . Regarding the contraceptive method used previously, this information was only present in 286 (34.54\%) of the total number of medical records, the most mentioned being oral hormonal contraceptives (OCA) by 130 (15.70\%) women, followed by the method male barrier as a condom by 88 (10.63\%) of them, as shown in Table 2.

At the time of insertion, 815 (98.43\%) of the women did not present any complications, however, it was found 11 (1.32\%) records of this nature and in two (0.24\%) records did not contain this information. Among the registered complications, the most prevalent, seen in seven medical records, was bleeding and, with one case each, bacterial vaginosis, skin pallor, nausea and need to change the Device.

From 828 women who received the IUD, the return was performed by 477 (57.61\%) of them and from these, 217 had some complaint, the most prevalent being dysmenorrhea in 68 (8.21\%) records, as shown in Table 3.

The expulsion of the IUD was found in 33 (3.98\%) of the medical records. Regarding the time of insertion, there is a significant difference between women who received the IUD at the Obstetric and Outpatient Center in terms of

Table 2 - Contraceptive methods previously used by women who receive the IUD in a low-risk maternity hospital-Curitiba, PR, Brazil, 2016-2017 ( $\mathrm{n}=828)$

\begin{tabular}{|c|c|c|}
\hline Previously used method & $\mathbf{n}$ & (\%) \\
\hline No Information & 542 & 65.46 \\
\hline OCA & 130 & 15.70 \\
\hline Male condom & 88 & 10.63 \\
\hline Quarterly injectable & 19 & 2.29 \\
\hline Monthly injectable & 17 & 2.05 \\
\hline IUD & 11 & 1.33 \\
\hline Deny use & 10 & 1.21 \\
\hline Vaginal ring & 4 & 0.48 \\
\hline OCA (mini-pill) & 3 & 0.36 \\
\hline Table & 1 & 0.12 \\
\hline IUD and condom & 1 & 0.12 \\
\hline OCA and condom & 1 & 0.12 \\
\hline OCA and injectable monthly and quarterly & 1 & 0.12 \\
\hline
\end{tabular}

Source: Research data, 2016-2017. 
Table 3 - Intercurrences presented in the 30 days return by women who had the IUD in a low-risk maternity hospital Curitiba, PR, Brazil, 2016-2017 ( $\mathrm{n}=217)$

\begin{tabular}{|c|c|c|}
\hline Intercurrence & $\mathbf{n}$ & (\%) \\
\hline Dysmenorrhea & 68 & 31.33 \\
\hline Bacterial vaginosis & 47 & 21.65 \\
\hline Menorrhagia & 32 & 14.74 \\
\hline Metrorrhagia & 24 & 11.05 \\
\hline Dyspareunia & 13 & 5.99 \\
\hline Partner Feels the IUD Wire & 10 & 4.60 \\
\hline Leukorrhea & 5 & 2.30 \\
\hline IUD not seen & 4 & 1.84 \\
\hline Myometrial perforation & 2 & 0.92 \\
\hline Headache & 2 & 0.92 \\
\hline Dysuria & 2 & 0.92 \\
\hline Intestinal Changes & 2 & 0.92 \\
\hline Intraepithelial Injury & 1 & 0.47 \\
\hline Urinary infection & 1 & 0.47 \\
\hline Endometritis & 1 & 0.47 \\
\hline Dizziness & 1 & 0.47 \\
\hline Polaciuria & 1 & 0.47 \\
\hline Irritability & 1 & 0.47 \\
\hline
\end{tabular}

Source: Research data, 2016-2017.

the expulsion rate $(\mathrm{p}=0.00001)$, with an 8.73 times greater chance of expulsion when the procedure is performed in the Obstetric Center right after delivery (Odds ratio 8.73).

Regarding the place of insertion of the device in the maternity hospital, in relation to the procedures performed in the Outpatient Clinic (late postpartum or on request) by the doctor and the nurse regarding expulsion, it was found that there was no significant difference between nurses and doctors ( $p=0.07$ ), however, there was 3.61 times (Odds ratio 3.60750) more chances to have expulsion when the person responsible for placement was the doctor (Table 4).
It is noteworthy that the number of medical professionals who perform the procedure is higher than nurses, given the presence also of resident doctors in the place.

As for the expulsion relationship with the number of vaginal deliveries, 17 (3.29\%) nulliparous or primiparous women had expulsion, while 16 (5.13\%) women with two or more vaginal deliveries had expulsion. It was observed that there is no significant relationship between the number of vaginal deliveries and the percentage of expulsion ( $p=0.19)$, however, women who had a vaginal delivery had a 1.5 more chance of expulsion (Odds ratio 1.55656). 
Table 4 - Relation between the expulsion rate, responsible professional, place of insertion and number of deliveries by women who receive the IUD in a low-risk maternity hospital - Curitiba, PR, Brasil, 2016-2017

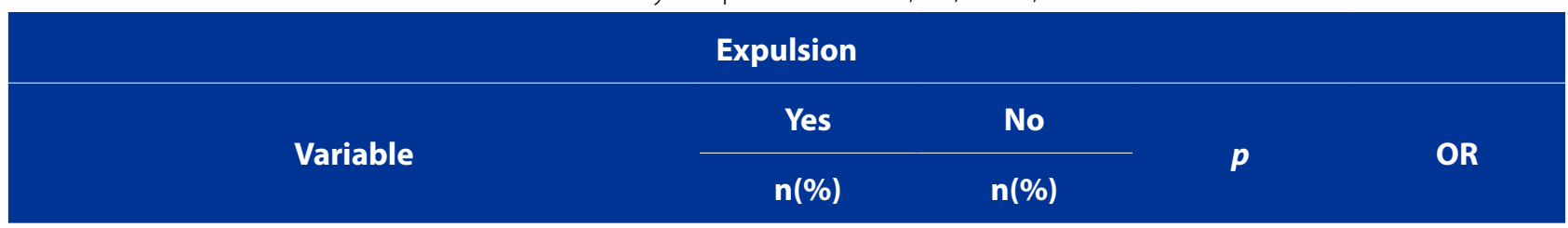

\section{Responsible professional (Outpatient Clinic)}

$\begin{array}{lcccc}\text { Nurse } & 4(0.83) & 477(99.17) & 0.07 & 3.61 \\ \text { Doctor } & 3(3.00) & 97(97.00) & & \end{array}$

Place of Insertion

Obstetric Center

$26(10.73) \quad 221(89.47)$

Outpatient Clinic

$7(1.20) \quad 574(98.80)$

0.00001

8.73

\section{Childbirth}

$\begin{array}{lllll}0 \text { or } 1 & 17(3.29) & 499(96.71) & 0.19 & 1.55 \\ 2 \text { or more } & 16(5.13) & 296(94.87) & & \end{array}$

Source: Research data, 2016-2017

\section{DISCUSSION}

In this study, it was noticed that the women attended, mostly, are young people of childbearing age, who have already had at least one pregnancy and sought the copper IUD as a method of reproductive planning, data that are similar to other studies, including other countries. Research carried out in a hospital in Recife, Brazil, with 157 women who received the copper IUD, the average age was 25 to 27 years $^{(9)}$. In Australia, from 207 women who received the device, they were between 16 and 50 years old, with an average of 33 years, of those 185 (89\%) had at least one previous delivery and 22 (11\%) were nulliparous ${ }^{(10)}$.

Regarding the education of women in this study, most had completed high school, attention is drawn to the number of women with or attending higher education, being similar to the study conducted in Recife, Brazil, in which, among the women who received the IUD, nulliparous women on average had completed high school and those who had a previous delivery did not complete it $\mathrm{it}^{(9)}$. What differs from the research carried out in a hospital in Pakistan, from the total of 1,230 women who received the copper IUD after delivery, 918 (73.4\%) did not have high school(11).
Regarding the methods used previously by the IUD for reproductive planning, the combined oral contraceptive was the most reported use before the choice of the copper IUD. A similar data was found, from the 157 women who received the Device in a hospital in Recife, 113 previously used hormonal oral contraceptives, followed by injectables (63) and more than half reported that the choice for the Device occurred due to the desire to abandon the use of hormones ${ }^{(9)}$. It is believed that the choice for copper IUD can occur for several reasons, among them, the fact that there are no hormones, less chance of contraceptive failure due to the fact of not needing to remember about daily intake, durability of the action, among others.

Thus, there is a need to disseminate and encourage reproductive planning by Brazilian health services, given the fragility of accessible information and the difficulty of women in associating their reproductive goals with the use of a safe, effective and compatible method for their well-being. Some women report that in the sexual initiation the male barrier method is used, however abandoned with the stabilization of the relationship, later they resort to oral contraceptives, but due to the side effects, they abandon it, leading to unplanned pregnancies. Thus, in order to guarantee women's sexual and 
reproductive rights, it is necessary to expand the strategies for their effective concretizing ${ }^{(12)}$, thus the insertion of IUD by nurses becomes a strategy for expanding both the supply of contraceptive methods and the range of professionals qualified for insertion.

In this study, the professionals who performed the insertion of the IUD were doctors and nurses, the latter has the practice of insertion already consolidated in several countries, such as England ${ }^{(13)}$, Tanzania ${ }^{(14)}$ and in the United States, which are properly trained they can insert reversible, long-acting contraceptive methods, such as copper and hormonal IUD (15). In Australia, since 2012, the Family Planning Service of New South Wales, an organization linked to the government, started training nurses to insert hormonal and copper IUD (10). And, in India, since 2013, the government changed its policy so that nurses and trained midwives could insert IUD after delivery and started trainings for the effectuation of such practice by the country in order to improve and encourage reproductive planning ${ }^{(16)}$.

Research carried out in Australia, between February 2012 and May 2014, followed four nurses trained to insert IUD and found that, from the 207 procedures performed, 194 (93.7\%) were performed successfully and without complications, in $13(6,3 \%)$ it was needed help from another professional or it was not possible the insertion, and the main reasons were patients who had internal cervical orifice stenosis, obtaining support from another professional to assess the size or position of the uterus, abnormal cytopathological results, request local anesthesia and support due to failure of the Device's release mechanism ${ }^{(10)}$.

Regarding to the return to the service for monitoring intercurrences, in this investigation, it was $57.6 \%$, a data similar to that found in other services, such as in Australia where the rate of return was $53 \%{ }^{(10)}$. Among the intercurrences recorded in the medical records of this study, dysmenorrhea and bacterial vaginosis were the most frequent. In a hospital in Pakistan 1,250 women who were followed up for six months after copper IUD insertion after delivery, 833 had no complications, however among the 417 women who did, menstrual disorder (238) and vaginal discharge (193) were observed ${ }^{(11)}$. The increase in the volume of vaginal bleeding was also the most reported complaint after return in two studies, one in Brazil ${ }^{(9)}$ and another in India ${ }^{(17)}$.

A systematic review showed that the risk of adverse outcomes related to unplanned pregnancy, perforation, infection, heavy bleeding or removals by bleending among young IUD users is low and may not be clinically significant, however, the risk of expulsion is greater in younger women compared to older women. However, the IUD is a safe, reversible and highly effective contraception method ${ }^{(18)}$.
Regarding the IUD expulsion rates, this study showed that it was higher when the insertion is performed in the immediate postpartum period at the Obstetric Center and data from the literature confirm these results. A systematic review found that immediate postpartum insertions, after ten minutes and 48 hours after delivery, resulted in higher expulsion rates than insertion between four and six weeks after delivery or insertion in women who were not in the postpartum period ${ }^{(19)}$. A cohort conducted in the United States followed 96 women who received the hormonal (55) and copper (41) IUD immediately after delivery, from these 21 hormonals and only 8 copper IUDs were expelled, of which 25 occurred within the first six weeks postpartum. In this study, women who received the hormonal IUD were more likely to expel the Device compared to those who received the copper IUD(20).

Regarding the moment of IUD insertion, in this study only medical professionals performed it at the Obstetric Center, in the immediate postpartum period, however, research in other countries shows that nurses, when trained, perform this practice routinely and safely, a study conducted in the United States demonstrated that from 123 IUD insertions, 68 (55\%) hormonal and 55 (45\%) copper performed in the immediate postpartum period, 53 (43.1\%) were by nurses who are specialists in obstetrics or women's health ${ }^{(20)}$. A study carried out in India showed that the insertion of IUD in the immediate postpartum period by properly trained nurses is as safe as that performed by doctors ${ }^{(16)}$.

In a Tanzania hospital (14)from the 596 copper IUD insertions in the immediate postpartum performed by trained midwives, only 43 women experienced complications in the return visit six weeks after insertion, among them, 14 (2.3\%) expulsions, 16 (2.7\%) uterine infections and 26 (4.4\%) removal requests. Data that reinforce the findings in this study and in this population investigated in relation to the practice of inserting copper IUD by nurses and doctors are safe when compared.

Thus, where human resources for health are an issue, allowing Nurses and obstetric specialists to perform IUD insertions can promote access to postpartum family planning and reduce the unmet need for contraception by women, especially in services that serve low-income populations and places where doctors are scarce ${ }^{(14)}$.

Finally, regarding expulsion in relation to parity, a study that investigated 84 nulliparous women and 73 women with previous delivery who received the copper IUD in a hospital in Recife, Brazil, showed that the rate of discontinuity of the method by expulsion was similar in both groups, $9.6 \%$ and $6.8 \%$ respectively ${ }^{(9)}$, a similar data to that found in this study regarding the expulsion rate in relation to parity. 


\section{CONCLUSION}

The present study made it possible to learn about the production of the practice of inserting copper IUD by nurses. The intercurrence and expulsion rates were lower than those presented in the literature and the insertion of the IUD, in the late postpartum period and at the request of women of childbearing age by the nurse, in this population, proved to be as safe as that performed by the doctor. Nevertheless, this study made it possible to know the population of women who received the device during this period, being young, with a good level of schooling, primiparous and in late postpartum.

In view of the results found, it is emphasized the importance of the insertion of nurses and their productivity in the insertion of IUD in view of the guarantee of sexual and reproductive rights from primary care to the hospital level. Therefore, it is reinforced the need to increase the supply of training courses for these professionals in view of the benefits to society, in terms of increasing the offer of this method in the long term and free of hormones, and services, in increasing the procedures offered with quality, safety and not focused on just one professional category.

Attention is also drawn to the incentive for the insertion of IUD by this professional in the immediate postpartum period, which is yet another strategy to encourage reproductive planning, expanding the offer of safe contraceptive methods and reducing unplanned pregnancies in the country.

It is recommended that studies of this nature in places where IUD insertion occurs by nurses are carried out and published in order to strengthen and encourage other services, as this practice performed by this professional is in constant legal discussion. It points out to the limitations of this investigation, as it occurred in only one maternity hospital in the municipality with temporal delimitation.

\section{REFERENCES}

1. Ministério da Saúde (BR). Blog da Saúde [Internet]. Brasília; c2016-2020 [cited 2018 Mar 28]. Conheça os métodos contraceptivos oferecidos pelo SUS; [about 1 screen]. Available from: http://www.blog.saude.gov.br/index.php/materiasespeciais/51645-saiba-mais-sobre-os-metodos-contraceptivos-oferecidospelo-sus

2. Federação Brasileira das Associações de Ginecologia e Obstetrícia. Manual de anticoncepção [Internet]. São Paulo: Federação Brasileira das Associações de Ginecologia e Obstetrícia; 2015 [cited 2017 Mar 27]. Available from: https:// armazemdaciencia.files.wordpress.com/2017/08/manual-anticoncepcaofebrasgo-2015-pdf.pdf
3. World Health Organization (CH). Selected practice recommendations for contraceptive use. Geneva:WH0; 2016 [cited 2018 Mar 20]. Available from: http:// apps.who.int/iris/bitstream/10665/252267/1/9789241565400-eng.pdf

4. World Health Organization. Medical eligibility criteria for contraceptive use. Fifth edition. Geneva: WHO; 2015 [cited 2018 Mar 20]. Available from: http://apps. who.int/iris/bitstream/10665/181468/1/9789241549158_eng.pdf

5. Lopez LM, Bernholc A, Hubacher D, Stuart G, Van Vliet HAAM. Immediate postpartum insertion of intrauterine device for contraception. Cochrane Database Syst Rev. 2015;(6):CD003036. doi: https://doi.org/10.1002/14651858. CD003036.pub3

6. Presidência da República (BR) Decreto de Lei n. 7.498, de 25 junho de 1986. Dispõe sobre a regulamentação do exercício da enfermagem, e dá outras providências. Brasília, DF; 1986 [cited 2018 Mar 20]. Available from: http:// www.planalto.gov.br/ccivil_03/leis//7498.htm

7. Conselho Federal de Enfermagem (BR). Resolução COFEN-358, de 15 de outubro de 2009. Dispõe sobre a Sistematização da Assistência de Enfermagem e a implementação do Processo de Enfermagem em ambientes, públicos ou privados, em que ocorre o cuidado profissional de Enfermagem, e dá outras providências. Brasília: COFEN; 2009 [cited 2018 Mar 20]. Available from: http:// www.cofen.gov.br/resoluo-cofen-3582009_4384.html

8. Conselho Federal de Enfermagem (BR). Parecer n. 17/2010/COFEN/CTLN, de 11 de novembro de 2010. Trata-se de encaminhamento dos documentos em epígrafe pela Secretaria do Conselho Federal de Enfermagem, para análise e emissão de Parecer sobre a "viabilidade dos Enfermeiros realizarem procedimentos com Medicamentos e Insumos para Planejamento Familiar Reprodutivo". Brasília: COFEN; 2010 [cited 2018 Mar 20]. Available from: http:// www.cofen.gov.br/parecer-n-172010-cofen-ctln_6148.html

9. Scavuzzi A, Souza ASR, Amorim MMR. Continued compliance and degree of satisfaction in nulligravida and parous women with intrauterine contraceptive devices. Rev Bras Ginecol Obstet. 2016;38(3):132-9. doi: https://doi. org/10.1055/s-0036-1580709

10. Kemeny F, Digiusto E, Bateson D. Insertion of intrauterine contraceptive devices by registered nurses in Australia. Aust N Z J Obstet Gynaecol. 2016;56(1):92-6. doi: https://doi.org/10.1111/aj0.12427

11. Wasim T, Shaukat S, Javed L, Mukhtar S. Outcome of immediate postpartum insertion of intrauterine contraceptive device: Experience at tertiary care hospital. J Pak Med Assoc. 2018 [cited 2018 Sep 26];68(4):519-25. Available from: https://jpma.org.pk/article-details/8637?article_id=8637

12. Medeiros TFR, Santos SMP, Xavier AG, Gonçalves RL, Mariz SR, Sousa FLP. Women's experience with contraception from the perspective of gender. Rev Gaúcha Enferm. 2016:37(2):e57350. doi: http://doi. org/10.1590/1983-1447.2016.02.57350

13. The Family Planning Association (UK). Your guide to the IUS: helping you choose the method of contraception that's best for you. Derby: FPA; 2018 [cited 2018 Sep 26]. Available from: https://www.fpa.org.uk/sites/default/files/ius-yourguide.pdf

14. Muganyizi PS, Kimario G, Ponsian P, Howard K, Sethi M, Makins A. Clinical outcomes of postpartum intrauterine devices inserted by midwives in Tanzania. Int J Gynecol Obstet 2018; 143(Suppl. 1):38-42. doi: https://doi.org/10.1002/ ijgo. 12603

15. Kelly PJ, Cheng AL, Carlson K, Witt J. Advanced practice registered nurses and long-acting reversible contraception. J Midwifery Womens Health. 2017;62(2):190-5. doi: https://doi.org/10.1111/jmwh.12578 
16. Yadav V, Balasubramaniam S, Das S, Srivastava A, Srivastava A, Kumar S, et al. Comparison of outcomes at 6 weeks following postpartum intrauterine contraceptive device insertions by doctors and nurses in India: a case-control study. Contraception. 2016;93(4):347-55. doi: https://doi.org/10.1016/j. contraception.2015.12.012

17. Blumenthal PD, Lerma K, Bhamrah R, Singh S, Dedicated PPIUD Inserter Working Group. Comparative safety and efficacy of a dedicated postpartum IUD inserter versus forceps for immediate postpartum IUD insertion: a randomized trial. Contraception. 2018;98(3):215-9. doi: https://doi.org/10.1016/j. contraception.2018.04.019
18. Jatlaoui TC, Riley HEM, Curtis KM. The safety of intrauterine devices among young women: a systematic review. Contraception. 2017;95(1):17-39. doi: https://doi.org/10.1016/j.contraception.2016.10.006

19. Sonalkar S, Kapp N. Intrauterine device insertion in the postpartum period: a systematic review. Eur J Contracept Reprod Health Care. 2015;20(1):4-18. doi: https://doi.org/10.3109/13625187.2014.971454

20. Goldthwaite LM, Sheeder J, Hyer J, Tocce K, Teal SB. Postplacental intrauterine device expulsion by 12 weeks: a prospective cohort study. Am J Obstet Gynecol. 2017;217(6):674.e1-674.e8. doi: https://doi.org/10.1016/j. ajog.2017.08.001

\section{- Corresponding author:}

Tatiane Herreira Trigueiro

Email: tatiherreira@gmail.com

\section{Associate editor:}

